\title{
Flere eldre plages med knesmerter
}

\section{USA oppgir flere og flere eldre at de har knesmerter. Likevel øker ikke forekomsten av røntgenverifisert gonartrose.}

I USA foretas det et økende antall kneoperasjoner med innsetting av totalprotese. Skyldes dette at befolkningen blir eldre og at folk blir tyngre?

Data fra flere studier ble samlet inn (1). Deltakerne i seks tverrsnittsstudier fra perioden 1971-2004, alle i alderen 60-74 år, ble spurt om de hadde knesmerter. Deltakerne i en kohortstudie ble spurt om knesmerter

og røntgenundersøkt i begge knær i 1983-85 og i 1992-93. Tilsvarende data ble samlet inn for deres avkom i 1992-95 og i 2002-05.

I tverrsnittsstudiene steg forekomsten av knesmerter, justert for alder og kroppsmasseindeks, med rundt $65 \%$ fra 1974 til 1994 blant hvite kvinner og menn og blant svarte kvinner. I kohortstudiene ble forekomsten

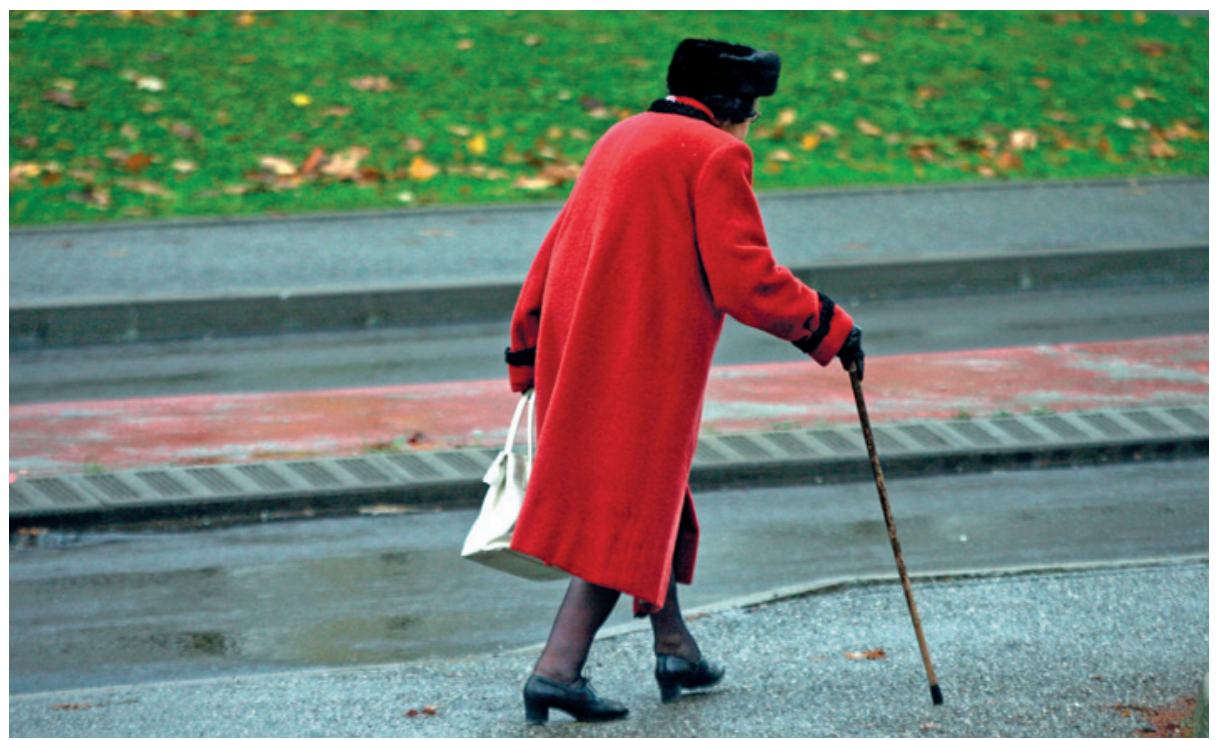

Illustrasjonsfoto Colourbox av knesmerter dobbelt så stor blant kvinner og tre ganger så stor blant menn i løpet av 20 år. Det ble ikke funnet en tilsvarende økning for radiologisk verifisert gonartrose. Forfatterne mener at funnene kan skyldes endringer i folks oppfattelse av smerter og at nye generasjoner eldre er mer villig til å rapportere smerte enn tidligere generasjoner.

- Denne studien bekrefter at stadig flere eldre er plaget med knesmerter og at dette bare delvis skyldes at folk er blitt tyngre, sier professor Ove Furnes ved Ortopedisk avdeling, Haukeland universitetssykehus. - Studien tyder på at knesmerter er et større helseproblem enn hittil antatt. Dette kan nok delvis forklares med lavere toleranse for smerter. Det er også mulig at urbane mennesker som beveger seg lite, får en sterkere smerteopplevelse av sitt artrosekne, ettersom flere studier har vist god effekt av fysisk aktivitet. I Norge settes det inn langt færre totale kneproteser per 100000 innbyggere (2) enn i USA, der omfattende reklame rettet mot både kirurger og pasienter driver antall prosedyrer opp, sier Furnes.

\section{Petter Gjersvik}

petjense@online.no

Tidsskriftet

\section{Litteratur}

1. Nguyen U-S, Zhang Y, Zhu Y et al. Increasing prevalence of knee pain and symptomatic knee osteoarthritis: survey and cohort data. Ann Intern Med 2011; 155: 725-32

2. Robertsson O, Bizjajeva S, Fenstad AM et al. Knee arthroplasty in Denmark, Norway and Sweden. Acta Orthop 2010; 81: 82-9.

\section{Genotype bestemmer effekt av blodplatehemmer}

\section{Noen pasienter bør antakelig få \\ langt høyere dose av blodplate- hemmeren klopidogrel.}

Blodplatehemmeren klopidogrel (Plavix) er et medikament som etter inntak omdannes til aktivt virkestoff via cytokrom P-450-enzymet CYP2C19. Genetisk variabilitet kan påvirke denne prosessen. En inaktiverende enzymvariant, CYP2C19*2, forekommer hos en relativt stor andel av befolkningen. Personer som er heterozygote for denne varianten, har redusert kapasitet til å danne den aktive klopidogrelmetabolitten, mens de homozygote langsomme omsetterne mangler evnen til metabolsk aktivering.

I en amerikansk multisenterstudie har man undersøkt effekten av klopidogrel hos 333 hjertesyke pasienter (1). Av disse var det
86 bærere av $C Y P 2 C 19 * 2$-genet -80 heterozygote og seks homozygote. Ikke-bærerne fikk først standarddosen på $75 \mathrm{mg}$ og deretter $150 \mathrm{mg}$ klopidogrel daglig, mens bærerne fikk økende doser fra $75 \mathrm{mg}$ til $300 \mathrm{mg}$ daglig. Endepunktet var blodplatereaktivitet målt med to ulike metoder. Gruppen som var heterozygote for CYP-varianten, fikk resultater som tilsvarte normaldosering hos ikkebærere når de økte til $225 \mathrm{mg}$ eller $300 \mathrm{mg}$ daglig, mens de homozygote langsomme omsetterne ikke oppnådde ønsket effekt selv med høyeste dose.

- Skreddersøm av farmakoterapi basert på genetiske analyser har lenge opptatt farmakologer og farmakologisk interesserte klinikere, sier professor i farmakologi Lars Slørdal ved Norges teknisk-naturvitenskapelige universitet.

- Resultatene fra denne studien er viktige, selv om vi mangler informasjon om effekt på harde endepunkter. Det ser ut til at pasienter som er heterozygote for den inaktiverende mutasjonen $\mathrm{CYP} 2 \mathrm{C} 19 * 2$, altså den tallmessig største gruppen av farmakogenetiske «problempasienter», kan behandles med klopidogrel i tredobbelt dose. Langsomme omsettere bør trolig behandles med andre blodplatehemmere som ikke er CYP2C19-substrater. Genotyping kan derfor få følger for både medikamentvalg og dosering, sier Slørdal.

\section{Ragnhild Ørstavik}

ragnhild.orstavik@fhi.no

Tidsskriftet

\section{Litteratur}

1. Mega JL, Hochholzer W. Frelinger AL 3rd et al. Dosing clopidogrel based on CYP2C19 genotype and the effect on platelet reactivity in patients with stable cardiovascular disease. JAMA 2011; 306: 2221-8. 